\title{
Empirical Modeling of Hot Air-Drying Kinetics of Horseradish Dehydration
}

\author{
Mukesh Guragain \\ Department of Food and Nutrition, University of Wisconsin-Stout \\ 415 10th Avenue East, Menomonie, WI, 54751, USA \\ Pranabendu Mitra (Corresponding author) \\ Department of Food and Nutrition, University of Wisconsin-Stout \\ 415 10th Avenue East, Menomonie, WI, 54751, USA \\ Tel: 1-715-232-5332Ｅ-mail: mitrap@uwstout.edu
}

Received: April 8, 2020 Accepted: May 20, 2020 Published: June 5, 2020

doi:10.5296/jfi.v4i1.17152ＵRL: http://dx.doi.org/10.5296/jfi.v4i1.17152

\begin{abstract}
The preservation of perishable horseradish crop is essential to increase the shelf-life and supply year-round. Hot air-drying method is commercially viable for preserving fruits and vegetables. However, drying conditions such as drying temperature affect the drying kinetic and the final quality of dried products. It is necessary to understand how drying temperature and blanching affect the drying kinetics of horseradish for the prediction of the right drying conditions. The objective of this study was to investigate the hot air-drying kinetics by fitting commonly used five empirical models to establish right hot air-drying conditions for drying of horseradish. The unblanched (control, C) and blanched (B) horseradish slices were dried at 50,70 and $85^{\circ} \mathrm{C}$ until reaching to an equilibrium moisture content $(\mathrm{db})$. The moisture reduction data were collected at certain intervals and the moisture content data were converted to moisture ratio (MR). The MR data were used to predict the drying kinetics of horseradish drying using five empirical models. The results indicated that drying kinetics followed the constant drying rate period and falling rate period for all three drying temperatures. The five tested models were able to predict the drying kinetics with $\mathrm{R}^{2}$ (0.96-0.99) and RMSE (0.01-0.06) depending on the models and blanching. However, diffusion approach model was the best fitted model securing the highest $\mathrm{R}^{2}$ and the lowest RMSE. The findings of this research are expected to be significantly important for horseradish drying effectively.
\end{abstract}


Keywords: Horseradish preservation, Hot air-drying, Empirical modeling, Drying Kinetic

\section{Introduction}

Due to lack of applications of right postharvest processing technologies on time about one third of the global food production is lost and the loss is even more for fruits and vegetables in developing countries because about $30-40 \%$ fruits and vegetables are wasted every year (Kumar, Karim, \& Joardder, 2014). Fruits and vegetables are considered as rich sources of dietary nutrients (i.e. vitamins, minerals and fibers etc.). Horseradish is a vital crop which is being used as food ingredients for many commercial food products such as sauces and condiments (Mitra, Alim, \& Meda, 2019). So, the horseradish has been an important crop in parts of Europe and significant production also exists in the U.S and Canada. About 3,500 to 4,000 acres are being cultivated annually in USA (Bratsch, 2009). The primary market for horseradish is for condiment makers (Bratsch, 2009; Mitra et al., 2019). The fruits and vegetables are classified as highly perishable commodities because of their high moisture content (Orsat, Changrue, \& Raghavan, 2006). A large cold storage area is needed to preserve perishable vegetables. The need of cold environment and large storage area are limiting factors for longer period of horseradish storage (Mitra et al., 2019). In order to overcome this problem and increased the shelf-life of horseradish the horseradish roots can be stored and preserved alternatively for a long time by dehydrating them to a low moisture content which is also desirable for production of many instant and convenient foods formulations.

Drying is one of the most widely and commonly used technique for food preservation (Meda, Mitra, Lee, \& Chang, 2016; Mitra \& Meda, 2009; Mitra, Meda, \& Green, 2013; Nagalakshmi, Mitra, \& Meda, 2014). Drying decreases the water activity of the materials, reduces the microbiological activity and minimizes physical and chemical changes in the foods (Ekechukwu, 1999; Mitra \& Meda, 2009). Over 20\% of the world perishable crops are dried to increase shelf-life which helps to fight against the food insecurity of the growing population (Sagar \& Suresh Kumar, 2010). The demand for the dehydrated fruits and vegetables is increasing every year. Because the growth in popularity of convenience foods such as dehydrated food mix, snacks and instant noodles in many countries has triggered the demand for high-quality dehydrated fruits and vegetables. There is a large market for dehydrated grapes, garlic, onions and tomatoes in USA. Dehydrated products have gained huge popularity because of their storage life, ease of handling and increased usage in preparation of instant and continental foods. Different value-added products from horseradish crop are a growing interest for small scale and new horseradish growers. Drying effects of different industrially feasible drying techniques in relation to quality parameters should be studied to increase the production of value-added dehydrated horseradish. The effective and efficient drying methods for horseradish drying and their drying kinetics are necessary considering quality concerns of consumers.

Drying introduces heat to materials which results in transfer of moisture within materials to their surfaces and then removes the surface water to atmosphere. Solar/Sun drying was used for drying of fruits and vegetables in many countries from primitive age (Ekechukwu, 1999; Kumar et al., 2014). Since solar drying is not very effective for the retention of the quality of 


\section{MInstitute Macrothink $_{\text {Int }}$}

the dried products and uncontrol drying conditions, many drying techniques (hot air drying, vacuum drying, microwave-vacuum drying and freeze drying etc.) have been developed over the years (Mitra et al., 2013; Orsat et al., 2006; Sagar \& Suresh Kumar, 2010) and except the freeze-drying technique, applying heat during drying through conduction, convection and radiation are the basic techniques used to force the water to vaporize, while forced air is applied to remove the vapor from the surface of materials to be dried. Considering advantages and disadvantages of different drying methods, hot air dying method is one of the most feasible methods for drying of fruit and vegetables commercially because this method is cheaper compared to some other drying such as freeze drying and this method is efficient for dying of agricultural crops (Mitra et al., 2019). Although there are many researches on drying of different fruits and vegetables to study the feasibility and drying kinetics of dried crops, there was not much literature on dehydration of horseradish. Since drying temperature affects the drying rate of materials significantly and the quality of the dried products depends on drying rate/drying kinetic. It is necessary to establish the drying kinetic models of hot air drying of horseradish for different temperatures to establish right drying time and drying rate for a drying temperature. The objective of this study was to investigate the hot air-drying kinetics by fitting commonly used empirical models to establish right hot air-drying conditions for drying of horseradish.

\section{Materials and Methods}

\subsection{Materials and Sample Preparation}

The Huntisinger Farms, Eau Claire, USA donated fresh horseradish roots and the horseradish roosts were stored at $4^{\circ} \mathrm{C}$ before drying sample preparation. Horseradish roots were sorted and cleaned under running water to remove the adhering foreign materials. The cleaned and sorted horseradish roots were sliced to a thickness of $3 \mathrm{~mm}$ using a mechanical slicer. The sliced samples were divided into two parts. One part was considered as control (C, unblanched) and another part was considered as blanched (B). The both control (C) and blanched (B) samples were dried using hot air-dying method to determine drying kinetics for right drying conditions.

\subsubsection{Blanching of Horseradish Slices}

The horseradish slices were submerged in hot water at $(95 \pm 2)^{\circ} \mathrm{C}$ for 2 minutes for a quick blanching treatment. After blanching, the horseradish slices were cooled to room temperature $\left(20^{\circ} \mathrm{C}\right)$ under cold running water and the surface water was removed with a tissue paper. The blanching was conducted to inactive enzymatic reactions before drying and compare the drying kinetics with control (unblanched) horseradish slices.

\subsection{Hot Air-Drying of Control (C, Unblanched) and Blanched (B) Horseradish}

About $100 \mathrm{~g}$ horseradish slices were spread uniformly in an aluminum tray (single layer) and were dried at 50,70 and $85^{\circ} \mathrm{C}$ using a conventional mechanical hot air oven (Linder Bleu, model - M01450A/SA). The initial weight of samples (before drying) was recorded and the weights of samples during drying for each drying temperature were measured at every 5 minutes for the first hour of drying, every 10 minutes for the second hour of drying and every 


\section{MInstitute ${ }^{\text {Macrothink }}$}

30 minutes afterwards until the samples reached to a constant weight (equilibrium condition) to complete the drying. The weights of the samples were measured using an ACCULAB-1200 (Sycamore, IL) model weighing balance with a readability of 0.01 gram. The final dried samples had less than $15 \%$ moisture content (wb). The drying kinetic data for the control (C) and blanched (B) horseradish samples dried at 50, 70 and $85^{\circ} \mathrm{C}$ were fitted to five empirical kinetic models (Table 1) to determine right drying conditions. Initial moisture content (before drying) and the final moisture content (end of drying) of the horseradish samples were determined using ASABE standard procedure-S410.2 (ASAE, 2010). Five grams horseradish was dried in a conventional hot air oven at $105^{\circ} \mathrm{C}$ for 24 hours. The experiment was done in triplicate and moisture content was reported as mean. Moisture content was determined for dry basis and wet basis by using the following formulas and was expressed in percentage $(\%)$.

\section{Qo Wet basts molsture content $\left(M C_{w b}\right)$ \\ $=\frac{\text { Inttlal weight }\left(W_{w}\right) \text { before drying }- \text { Ftral weight }\left(W_{d}\right) \text { after drytng }}{\text { Inttial wetght }\left(W_{w}\right) \text { before drying }} \times 100$}

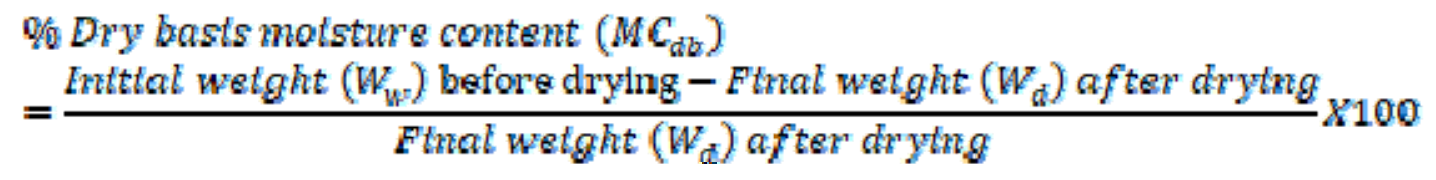

\subsection{Empirical Mathematical Modeling of Horseradish Drying Kinetics}

The drying kinetic is the rate of change of moisture of samples during drying. Since the drying rate is not constant over time, the typical drying kinetic follows the initial drying, constant drying rate and falling drying rate. This drying phenomenon can be represented by developing a drying curve with a relationship between moisture content and drying time to predict drying suitable conditions. In a common practice, the dry basis $\left(\mathrm{MC}_{\mathrm{db}}\right)$ moisture content of the samples is converted to a dimensionless moisture ratio (MR) and the drying kinetic curve is drawn by plotting MR versus drying time to fit the data for the desired empirical models. In this study, the different moisture content $(\mathrm{db})$ data for control $(\mathrm{C})$ and blanched (B) samples dried at 50,70 and $85^{\circ} \mathrm{C}$ were calculated as MR using the following equation.

$$
M R=\frac{\left(M-M_{\varepsilon}\right)}{\left(M_{0}-M_{\varepsilon}\right)}
$$

MR = Moisture Ratio (dimensionless number), $\mathrm{M}_{0}=$ Initial moisture content $(\mathrm{db}), \mathrm{M}=$ Moisture content $(\mathrm{db})$ at different drying time, $\mathrm{M}_{\mathrm{e}}=$ Equilibrium moisture content $(\mathrm{db})$ were considered in this above equation. The MR values and the drying times were fitted to five commonly used empirical models as shown in Table 1 to determine the drying kinetics and predict the moisture ratio (MR) according to the drying time. Non-linear regression techniques were used to obtain the specific constants in each of the selected models. In order to fit the data for the modeling, it was assumed that the samples used for drying contained the same initial moisture content and there was no loss of heat to the insulations of dryer. The 


\section{Al Macrothink}

internal temperature gradient in samples, drying air humidity, heat transfer between the material and volume contraction rate during the drying were negligible.

\subsection{Statistical Data Analysis}

The empirical models (Table 1) used in this study were solved by performing regression analysis using Microsoft Excel 2013 and it's add on XLSTAT to determine the constants and coefficients of empirical models tested and to compare the different models to find the best fitting hot air-drying model for each drying condition of horseradish. The coefficient of determination $\left(\mathrm{R}^{2}\right)$ was a primary criterion for selecting the best model to account for the variation in the drying curves of dried horseradish samples dried at 50,70 and $85^{\circ} \mathrm{C}$. The root mean square error (RMSE) was used to determine the goodness of fit of the models. The higher coefficient of determination $\left(\mathrm{R}^{2}\right)$ and lower root mean square error (RMSE) were considered as the best fitted model (Akpinar, 2006; Midilli \& Kucuk, 2003). The statistical parameters were calculated by using the following relationships (Dhanushkodi, Wilson, \& Sudhakar, 2017). Where, $\mathrm{MR}_{\exp }$ and $\mathrm{MR}_{\text {pre }}$ represent experimental moisture ratio and predicted moisture ratio, respectively.

$$
\begin{gathered}
A^{2}=\frac{\left[\sum_{i=1}^{N}\left(M R_{e x p, t}-\overline{M R_{e x p}}\right)\left(M R_{p r e, t}-\overline{M R_{p r e}}\right)\right]}{\sum_{i=1}^{N}\left(M R_{e x p, t}-\overline{M R_{p r e}}\right)^{2} \sum_{i=1}^{N_{i}}\left(M R_{p r e, t}-\overline{M R_{p r \varepsilon}}\right)^{2}} \\
R M S E^{2}=\sqrt{\left[\frac{1}{N} \sum_{i=1}^{N}\left(M R_{e x p, t}-M R_{p r e, t}\right)^{2}\right]^{2}}
\end{gathered}
$$

\begin{tabular}{|c|c|c|}
\hline Name of model & Equation & References \\
\hline $\begin{array}{l}\text { Diffusion } \\
\text { approach }\end{array}$ & $M R=a \exp (-k t)+(1-a) \exp (-k b t)$ & $\begin{array}{l}\text { Akpinar, 2006; Dhanushkodi et al., } \\
\text { 2017; Togrul \& Pehlivan, } 2002\end{array}$ \\
\hline Page & $M R=\exp \left(-k t^{n}\right)$ & $\begin{array}{l}\text { Akpinar, 2006; Dhanushkodi et al., } \\
\text { 2017; Midilli \& Kucuk, } 2003\end{array}$ \\
\hline $\begin{array}{l}\text { Henderson \& } \\
\text { Pabis }\end{array}$ & $\mathrm{MR}=\mathrm{a} \exp (-\mathrm{kt})$ & $\begin{array}{l}\text { Akpinar, 2006; Dhanushkodi et al., } \\
\text { 2017; Midilli \& Kucuk, } 2003\end{array}$ \\
\hline Two term & $M R=a \exp \left(-k_{0} t\right)+b \exp \left(-k_{1} t\right)$ & $\begin{array}{l}\text { Akpinar, 2006; Dhanushkodi et al., } \\
\text { 2017; Midilli \& Kucuk, } 2003\end{array}$ \\
\hline $\begin{array}{l}\text { Two-term } \\
\text { exponential }\end{array}$ & $M R=a \exp (-k t)+(1-a) \exp (-k a t)$ & $\begin{array}{l}\text { Akpinar, 2006; Dhanushkodi et al., } \\
\text { 2017; Midilli \& Kucuk, } 2003\end{array}$ \\
\hline
\end{tabular}

Table 1. Empirical thin layer drying models used in this study

$\mathrm{a}, \mathrm{b}, \mathrm{n}, \mathrm{k}_{0}, \mathrm{k}_{1}$ and $\mathrm{k}$ are model constants and coefficients 


\section{Macrothink}

\section{Results and Discussion}

\subsection{Effect of drying temperature and blanching on the drying kinetic of horseradish}

The unblanched (control, C) and blanched (B) horseradish samples were dried at 50, 70 and $85^{\circ} \mathrm{C}$ until reaching to a constant weight (equilibrium condition). The dry basis moisture content for certain intervals during drying as described in the drying method was determined and was converted to moisture ratio (MR). Since a drying kinetic curve determines a required drying time for products under certain conditions, the drying kinetic curves (MR versus drying time) for the horseradish drying were drawn as shown in Figure 1 to determine the drying time for three different drying temperatures.

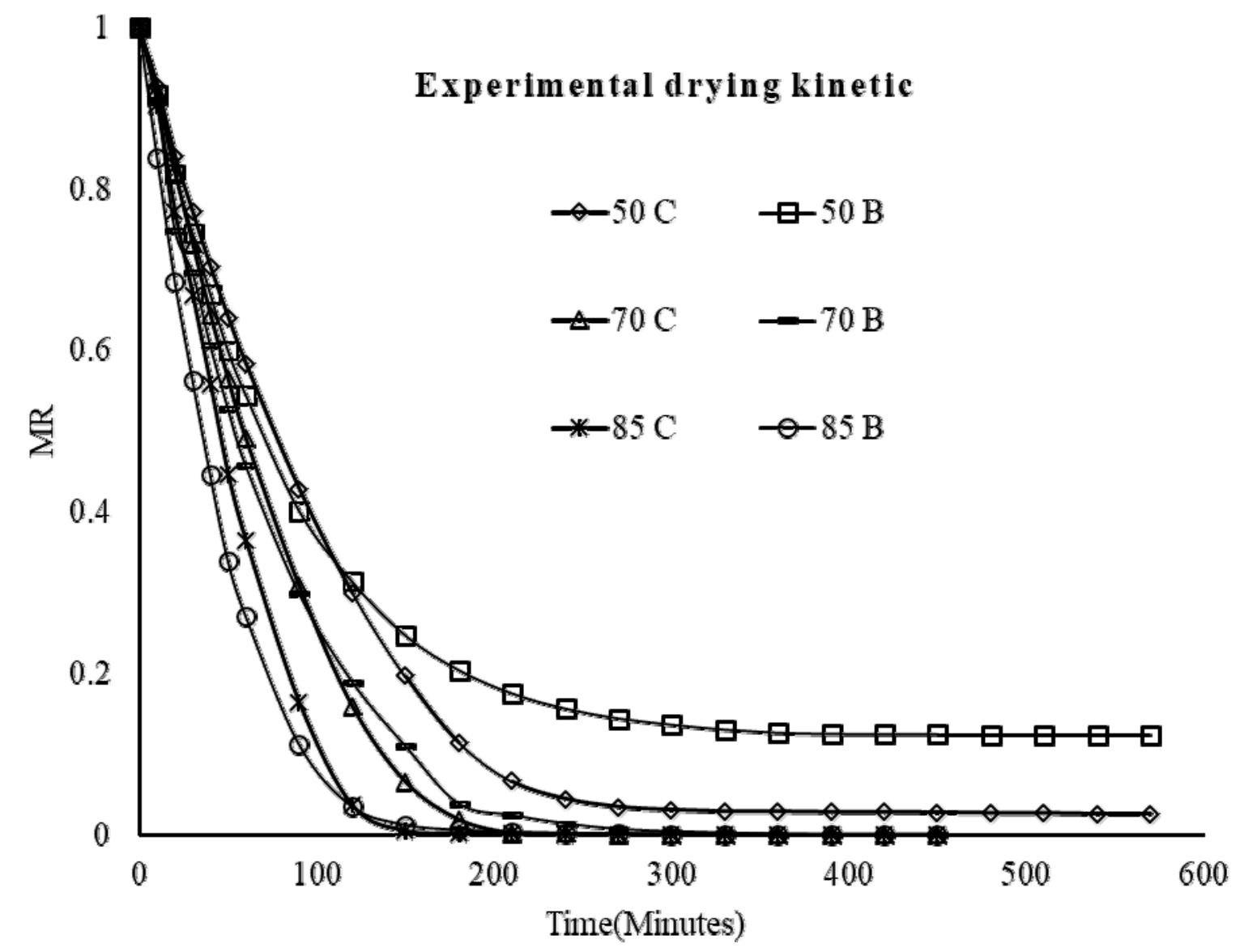

Figure 1. Experimental drying kinetic (relationship between MR and drying time) of unblanched (control, C) blanched horseradish samples dried at 50,70 and $85^{\circ} \mathrm{C}$.

The drying kinetic (Figure 1) indicated that all drying curves for control (C) and blanched (B) horseradish samples dried at 50,70 and $85^{\circ} \mathrm{C}$ followed a similar trend for constant drying rate period and falling drying rate period. A typical drying kinetic curve shows the initial drying warm-up time, constant drying rate period for removing free surface water and falling rate period for removing samples' inside water until reaching to an equilibrium moisture content. This study indicated that the drying kinetic curve showed constant drying rate period and falling rate period before reaching to an equilibrium moisture content (end of drying). 
Table 2. Modeling solutions (model parameters) of tested empirical models for unblanched (control, C) and blanched (B) horseradish samples dried at 50, 70 and $85^{\circ} \mathrm{C}$

\begin{tabular}{|c|c|c|c|c|c|c|c|}
\hline \multirow{3}{*}{ Models } & \multirow{3}{*}{$\begin{array}{l}\text { Model } \\
\text { Parameters }\end{array}$} & \multicolumn{2}{|c|}{ Drying temperature } & \multicolumn{2}{|c|}{ Drying temperature } & \multicolumn{2}{|c|}{ Drying temperature } \\
\hline & & \multicolumn{2}{|c|}{$\left(50^{\circ} \mathrm{C}\right)$} & \multicolumn{2}{|l|}{$\left(70^{\circ} \mathrm{C}\right)$} & \multicolumn{2}{|c|}{$\left(85^{\circ} \mathrm{C}\right)$} \\
\hline & & $\mathrm{C}$ & $\mathrm{B}$ & $\mathrm{C}$ & B & $\mathrm{C}$ & B \\
\hline & $\mathrm{a}$ & -0.53 & -0.07 & -1.08 & -0.60 & -1.20 & -6.01 \\
\hline \multicolumn{8}{|l|}{ Diffusion } \\
\hline & $\mathrm{b}$ & 0.53 & 0.92 & 0.60 & 0.62 & 0.60 & 0.91 \\
\hline & $\mathrm{k}$ & 0.02 & 0.01 & 0.03 & 0.03 & 0.05 & 0.04 \\
\hline & $\mathrm{k}$ & 0.01 & 0.03 & 0.01 & 0.01 & 0.01 & 0.01 \\
\hline \multicolumn{8}{|l|}{ Page } \\
\hline & $\mathrm{n}$ & 1.17 & 0.73 & 1.31 & 1.11 & 1.38 & 1.18 \\
\hline Henderson \& & $\mathrm{a}$ & 1.04 & 0.94 & 1.07 & 1.04 & 1.07 & 1.03 \\
\hline Pabis & $\mathrm{k}$ & 0.01 & 0.007 & 0.01 & 0.01 & 0.02 & 0.02 \\
\hline & $\mathrm{a}$ & 0.74 & 0.09 & 0.29 & 0.74 & 0.19 & 0.25 \\
\hline & $\mathrm{b}$ & 0.30 & 0.92 & 0.77 & 0.30 & 0.86 & 0.78 \\
\hline \multicolumn{8}{|l|}{ Two term } \\
\hline & $\mathrm{k}_{0}$ & 0.01 & -0.001 & 0.01 & 0.01 & 0.02 & 0.02 \\
\hline & $\mathrm{k}_{1}$ & 0.01 & 0.01 & 0.01 & 0.01 & 0.02 & 0.02 \\
\hline Two term & $\mathrm{a}$ & 0.002 & 0.29 & 0.001 & 0.001 & 0.001 & 0.001 \\
\hline exponential & $\mathrm{k}$ & 51.53 & 0.02 & 60.38 & 51.53 & 69.34 & 109.34 \\
\hline
\end{tabular}


Table 3. Statistical justification of fitting empirical tested models for unblanched (control, C) and blanched (B) horseradish samples dried at 50,70 and $85^{\circ} \mathrm{C}$

\begin{tabular}{|c|c|c|c|c|c|c|c|c|c|c|c|c|}
\hline \multirow{3}{*}{$\begin{array}{l}\text { Tested } \\
\text { models }\end{array}$} & \multicolumn{4}{|c|}{ Drying temperature $50^{\circ} \mathrm{C}$} & \multicolumn{4}{|c|}{ Drying temperature $70^{\circ} \mathrm{C}$} & \multicolumn{4}{|c|}{ Drying temperature $85^{\circ} \mathrm{C}$} \\
\hline & $\mathrm{C}$ & B & $\mathrm{C}$ & $\mathrm{B}$ & $\mathrm{C}$ & B & $\mathrm{C}$ & $\mathrm{B}$ & $\mathrm{C}$ & $\mathrm{B}$ & $\mathrm{C}$ & $\mathrm{B}$ \\
\hline & $\mathrm{R}^{2}$ & $\mathrm{R}^{2}$ & RMSE & RMSE & $\mathrm{R}^{2}$ & $\mathrm{R}^{2}$ & RMSE & RMSE & $\mathrm{R}^{2}$ & $\mathrm{R}^{2}$ & RMSE & RMSE \\
\hline $\begin{array}{l}\text { Diffusion } \\
\text { approach }\end{array}$ & 0.99 & 0.99 & 0.02 & 0.01 & 0.99 & 0.99 & 0.02 & 0.01 & 0.99 & 0.99 & 0.02 & 0.01 \\
\hline Page & 0.99 & 0.96 & 0.02 & 0.05 & 0.99 & 0.99 & 0.01 & 0.01 & 0.99 & 0.99 & 0.01 & 0.01 \\
\hline $\begin{array}{l}\text { Henderson } \\
\text { \& Pabis }\end{array}$ & 0.99 & 0.96 & 0.03 & 0.06 & 0.99 & 0.99 & 0.03 & 0.02 & 0.99 & 0.99 & 0.04 & 0.02 \\
\hline Two term & 0.99 & 0.99 & 0.03 & 0.01 & 0.99 & 0.99 & 0.04 & 0.02 & 0.99 & 0.99 & 0.04 & 0.02 \\
\hline $\begin{array}{l}\text { Two term } \\
\text { exponential }\end{array}$ & 0.99 & 0.97 & 0.03 & 0.05 & 0.99 & 0.99 & 0.04 & 0.02 & 0.99 & 0.99 & 0.04 & 0.02 \\
\hline
\end{tabular}

The initial warm-up period is required for product adjustment to ambient conditions. The invisibility of initial warm-up period is a common phenomenon for most products during drying. The constant drying rate period and falling rate period are vital for any drying kinetic curve. The experimental drying kinetic curves of this study were in the agreement with several studies done by many authors (Akpinar, 2006; Dhanushkodi et al., 2017; Ekechukwu, 1999; Midilli \& Kucuk, 2003; Togrul \& Pehlivan, 2002). However, the variability of the moisture reduction of horseradish samples during drying varied depending on drying temperature and blanching. The moisture ratio (MR) of blanched (B) samples was lower than the moisture ratio (MR) of control (C) samples for all three drying temperatures (Figure 1). This study indicated that horseradish samples absorbed about 5-7\% (wb) water during blanching. This absorbed water of the samples increased the initial moisture content which reduced the moisture ratio (MR) of the dried horseradish samples. This study indicated that drying temperature influenced the moisture reduction significantly. The higher drying temperature decreased the drying time of the samples to reach to an equilibrium moisture content. These results were in the agreement with other studies (Meda et al., 2016; Midilli \& Kucuk, 2003; Mitra et al., 2019; Orsat et al., 2006). This study indicated that the constant drying rate periods were 150, 220 and 280 minutes and complete drying times were 300,350 and 400 minutes (Figure 1) for horseradish samples dried at 85,70 and $50^{\circ} \mathrm{C}$, respectively. Drying driving potential increased with temperature because the higher drying temperature decreased the relative humidity and increased the water holding capacity of air passing over the materials to be dried. The drying rate of samples was increased due to acceleration of 
water diffusion from horseradish samples with a higher temperature (Babu, Kumaresan, Raj, \& Velraj, 2018; Mitra \& Meda, 2009). The faster movement of water from the center to the surface of horseradish due to higher drying driving potential reduced drying time when drying temperature increased from 50 to $85^{\circ} \mathrm{C}$. Also, heat and mass transfers of the horseradish samples increased with higher drying temperature. This phenomenon might cause the shorter drying time at $85^{\circ} \mathrm{C}$ compared to drying time at $50^{\circ} \mathrm{C}$.

\subsection{Empirical modeling of kinetic curve of horseradish drying}

The moisture content data of unblanched (C) and blanched (B) horseradish samples dried at 50,70 and $85^{\circ} \mathrm{C}$ for different drying time were transferred to MR (moisture ratio) and the MR data were fitted to five tested empirical models (Table 1) against drying time to determine the models constants $(\mathrm{a}, \mathrm{b}$ and $\mathrm{n})$ and coefficients/drying rate constants $\left(\mathrm{k}, \mathrm{k}_{0}\right.$ and $\left.\mathrm{k}_{1}\right)$ for the prediction of hot air drying kinetic of horseradish samples. The solutions (model parameters) of the tested models are shown in Table 2. The statistical justification of fitting empirical tested models for the drying of unblanched (control, C) and blanched (B) horseradish samples dried at 50, 70 and $85^{\circ} \mathrm{C}$ is presented in Table 3. The highest $\mathrm{R}^{2}$ and the lowest RMSE were considered to select the best fitted empirical model among five tested empirical models. The comparisons between experimental drying kinetic and predicted drying kinetic given by the best 3 empirical models are shown in Figure 2, Figure 3 and Figure 4 for horseradish samples dried at 50,70 and $85^{\circ} \mathrm{C}$, respectively.

The statistical results (Table 3) indicated that the values of $\mathrm{R}^{2}$ varied from 0.96 to 0.99 and the values of RMSE varied from 0.01 to 0.06 for all tested models. The $\mathrm{R}^{2}$ value was one of the measuring criterion to justify the good fit of any models and the value of $\mathrm{R}^{2}$ close to 1 was considered a good fit for a model (Bhaktaraj, Prajapati, Nepal, Timalsina, \& Mitra, 2019; Meda et al., 2016; Mitra, Chang, \& Yoo, 2011; Timalsina et al., 2019). The $\mathrm{R}^{2}$ values and the very low RMSE values of the five tested models revealed that all tested models could predict the drying kinetic of unblanched $(\mathrm{C}$, control) and blanched $(\mathrm{B})$ horseradish samples dried at 50,70 and $85^{\circ} \mathrm{C}$ reasonably accurate. However, the prediction capacity of different models varied depending on the drying temperature and blanching (Table 3 and Figures 2-4). Several studies (Akpinar, 2006; Dhanushkodi et al., 2017; Ekechukwu, 1999; Midilli \& Kucuk, 2003; Togrul \& Pehlivan, 2002) indicated that drying temperature affected the prediction capacity of empirical models. The blanching affected the drying kinetic of horseradish samples dried at $50^{\circ} \mathrm{C}$. The blanching decreased the prediction capacity of Page model $\left(\mathrm{R}^{2}=0.96\right)$, Henderson \& Pabis $\left(\mathrm{R}^{2}=0.96\right)$ and two term exponential model $\left(\mathrm{R}^{2}=0.97\right)$ by decreasing $\mathrm{R}^{2}$ and increasing RMSE of those models. The initial absorbed water by the horseradish samples during blanching and low drying temperature might affect the prediction capacity of those models. However, the drying kinetic of horseradish samples predicted by five tested models was not affected by the higher drying temperature $\left(70\right.$ and $\left.85^{\circ} \mathrm{C}\right)$. The higher drying rate of blanched (B) horseradish samples dried at higher temperature might adjust the initial absorbed water during blanching quickly and this phenomenon might improve the prediction capacity of all tested models for higher drying temperatures. 


\section{Mll Macrothink}
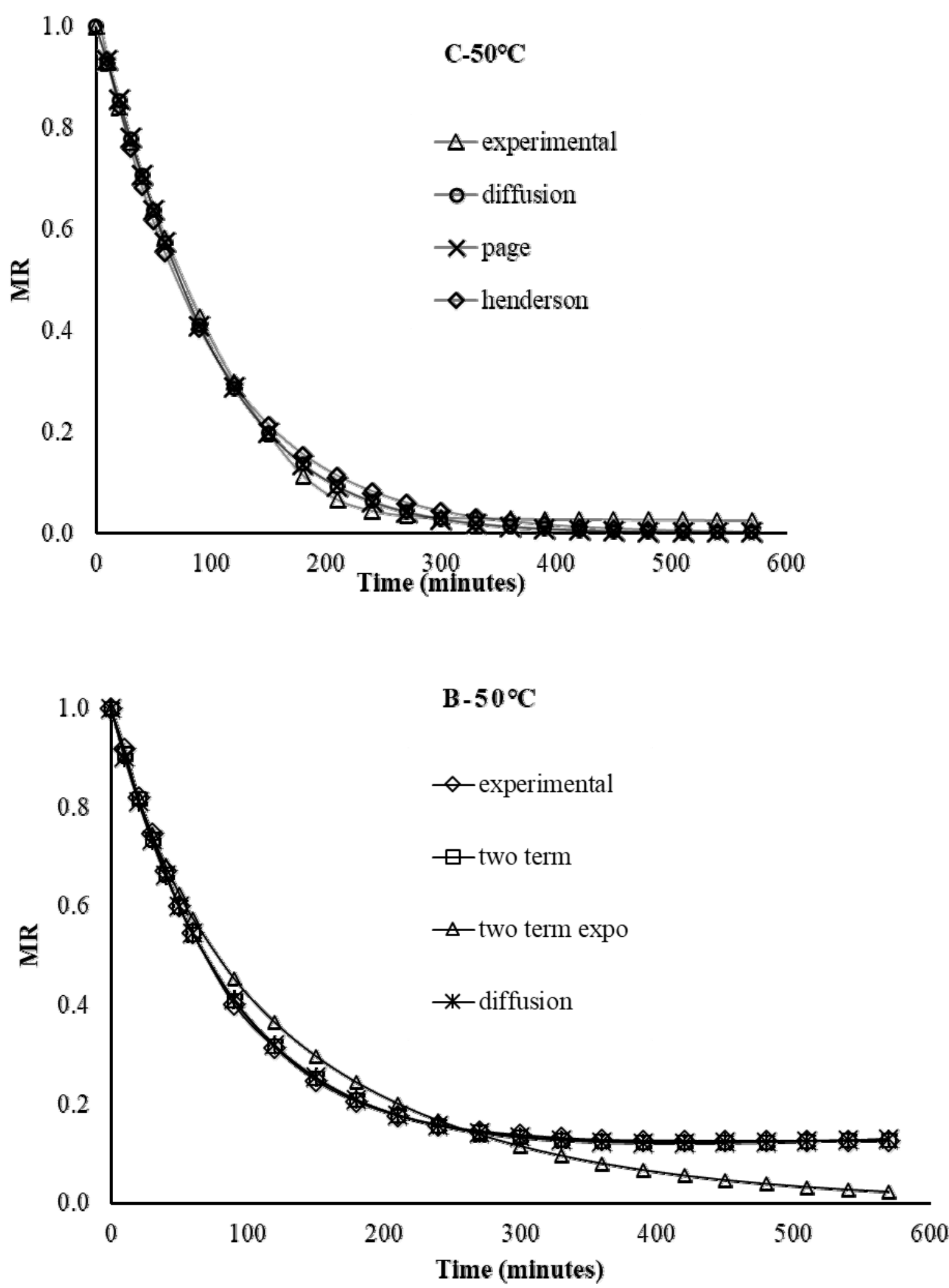

Figure 2. Comparison of drying kinetic (MR versus drying time) between experimental and predicted kinetic for 3 best fitted empirical models of the unblanched (control, C) and blanched (B) horseradish samples dried at $50^{\circ} \mathrm{C}$. 

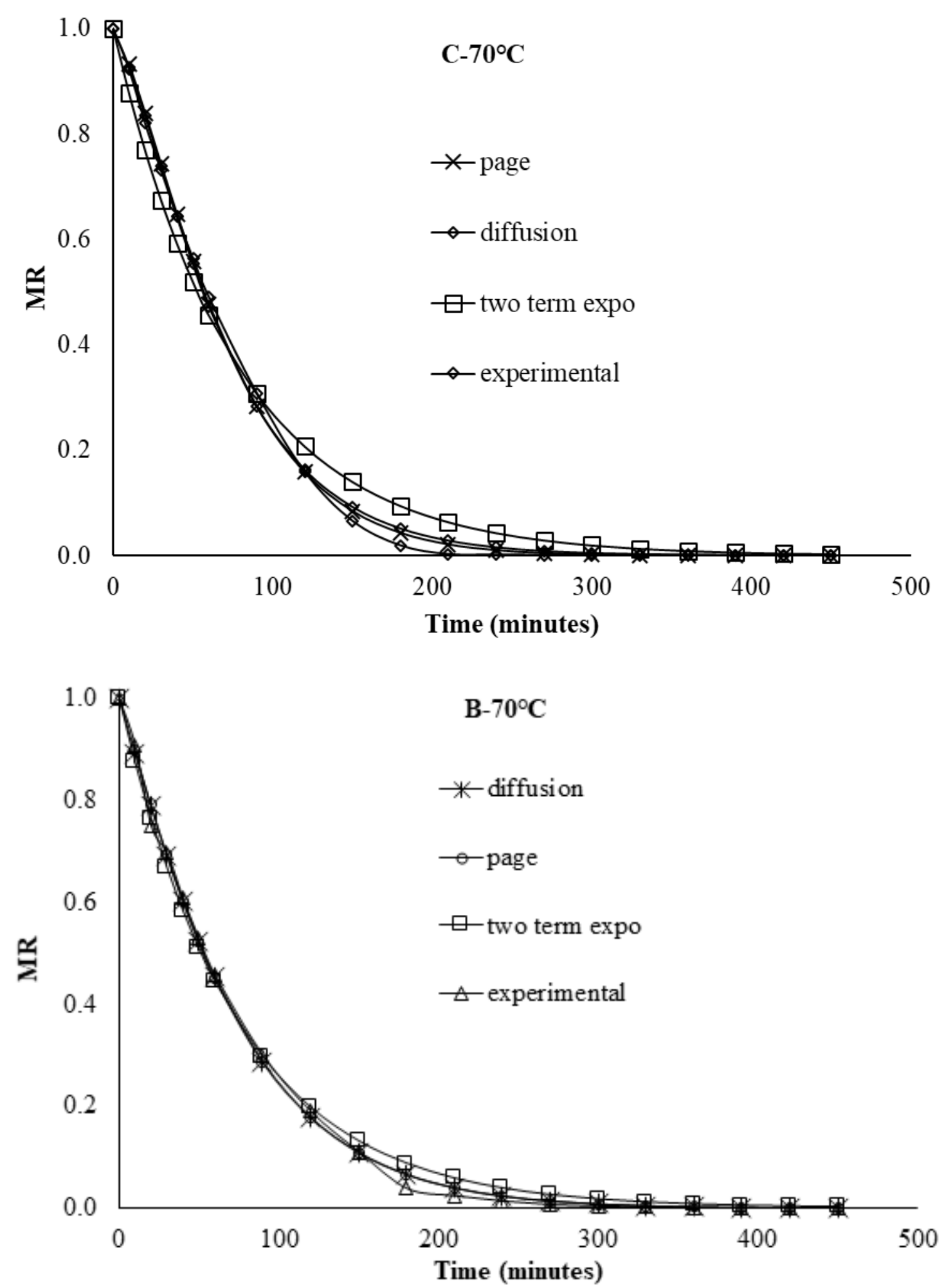

Figure 3. Comparison of drying kinetic (MR versus drying time) between experimental and predicted kinetic for 3 best fitted empirical models of the unblanched (control, $\mathrm{C}$ ) and blanched (B) horseradish samples dried at $70^{\circ} \mathrm{C}$. 


\section{Macrothink}
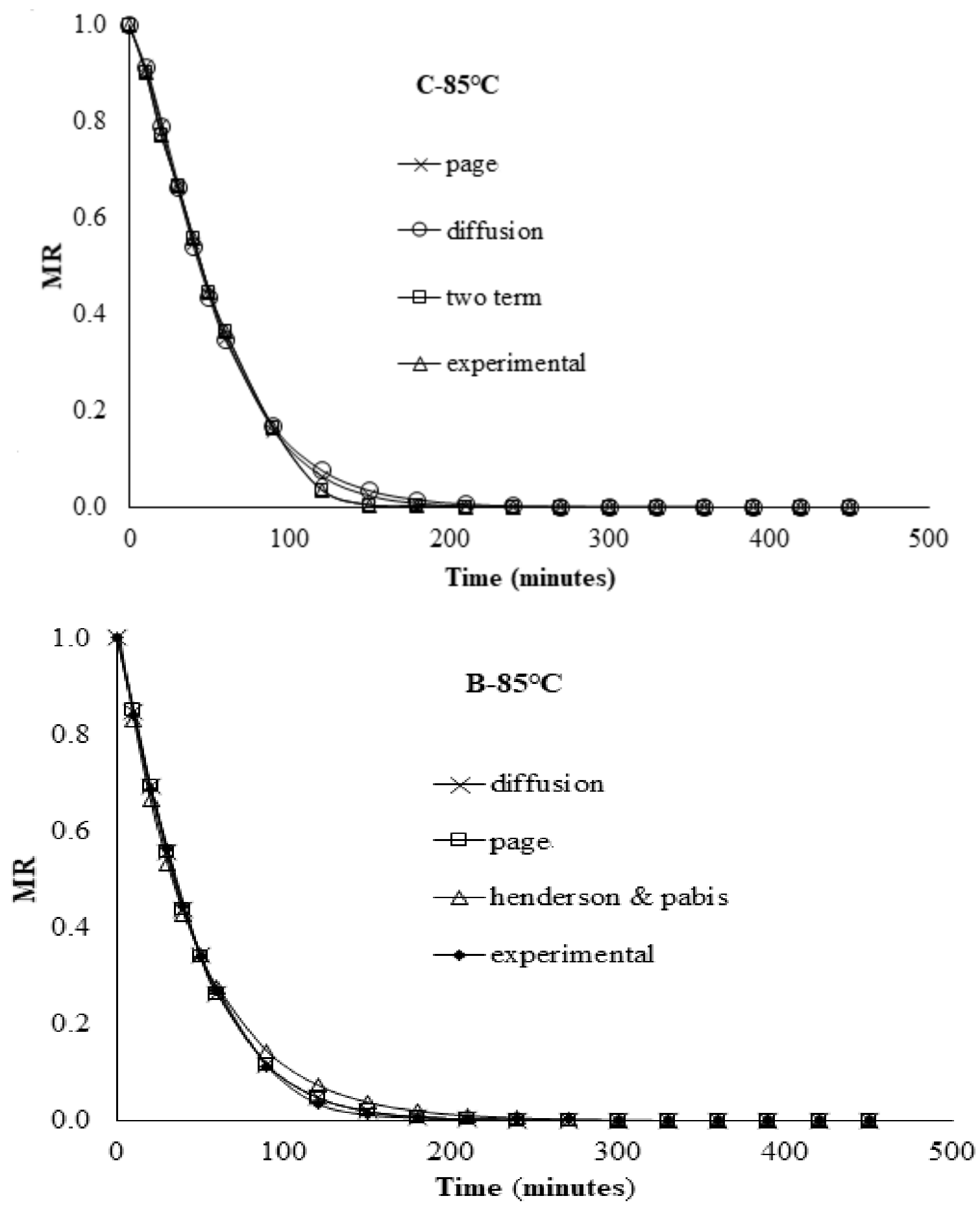

Figure 4. Comparison of drying kinetic (MR versus drying time) between experimental and predicted kinetic for 3 best fitted empirical models of the unblanched (control, C) and blanched (B) horseradish samples dried at $85^{\circ} \mathrm{C}$.

Overall, diffusion approach model was the best fitted model with the highest $\mathrm{R}^{2}(0.99)$ and the lowest RMSE (0.01) and was followed by Page model, Henderson \& Pabis model, two term exponential model and two term model (Table 3 and Figures 2-4) of unblanched (control, C) and blanched (B) dried horseradish samples for all three drying temperatures. The Figures 2-4 indicated that the predictive drying kinetic curve given by diffusion approach model was 
almost overlapped with the experimental drying kinetic curve. Beside diffusion approach model, Page model and two term exponential model showed a very good fit to predict the drying kinetic curve of unblanched (C) and blanched (B) horseradish samples dried at $70^{\circ} \mathrm{C}$ (Figure 3). Page model showed the best fit to predict drying kinetic curve for the unblanched (C) horseradish samples dried at $85^{\circ} \mathrm{C}$. Diffusion model was the second-best model for predicting drying characteristics for this drying condition. But diffusion model was the best fitted model for the prediction of drying of blanched (B) horseradish samples dried at $85^{\circ} \mathrm{C}$ and Page model was the second-best model for predicting drying kinetic curve for this drying condition securing the highest $\mathrm{R}^{2}$ and the lowest RMSE (Table 3 and Figure 4). The results of this study were in the agreement of many studies conducted by many scientists (Akpinar, 2006; Dhanushkodi et al., 2017; Ekechukwu, 1999; Midilli \& Kucuk, 2003; Orsat et al., 2006; Togrul \& Pehlivan, 2002). Diffusion approach model was most suitable to describe the microwave drying kinetics of the olive pomace (Sadi \& Meziane, 2015) and the thin layer drying kinetics of cashew biomass (Dhanushkodi et al., 2017). Many research studies (Akpinar, 2006; Dhanushkodi et al., 2017; Ekechukwu, 1999; Midilli \& Kucuk, 2003; Orsat et al., 2006; Sadi \& Meziane, 2015; Togrul \& Pehlivan, 2002) found that Page, Henderson \& Pabis, two term and two term exponential models were very effective to describe the drying kinetics of the various fruits and vegetables successfully.

\section{Conclusion}

The results indicated that the drying rate ( $\mathrm{k}$ value) increased with increased drying temperature from 50 to $85^{\circ} \mathrm{C}$. The experimental drying kinetic showed constant drying rate period and falling drying rate period for unblanched (control, C) and blanched (B) horseradish samples dried at 50,70 and $85^{\circ} \mathrm{C}$. The relationship between moisture ratio (MR) and drying time could be predicted by diffusion approach model, Page model, Henderson \& Pabis model, two term model and two term exponential model effectively. However, the variability of the prediction capacity depended on the models, drying temperature and blanching treatment of samples. Diffusion model was best for all drying temperatures tested securing the highest $\mathrm{R}^{2}(0.99)$ and the lowest RMSE (0.01). Page model was also good for all temperatures, but Page model was most effective for higher temperature $\left(85^{\circ} \mathrm{C}\right)$. Overall, all five tested models were able to predict the drying kinetic of horseradish samples with an accuracy of $99-96 \%$ depending on the model and drying temperature.

\section{Acknowledgement}

The research was funded by the University of Wisconsin-Stout Discovery Center Research Fellow grant and by the Maybelle Ranney Price Professorship (CEHHHS-GM-00295-1-A-20) professional development grant, University of Wisconsin- Stout, USA. The horseradish bulk samples were donated by the Huntsinger Farms Inc., Eau Claire, WI, USA.

\section{References}

Akpinar, E. K. (2006). Determination of suitable thin layer drying curve model for some vegetables and fruits. Journal of Food Engineering, 73(1), 75-84. https://doi.org/10.1016/j.jfoodeng.2005.01.007 
ASAE. (2010). Moisture Measurement--Peanuts (S410.1). St. Joseph, MI: ASABE. https://doi.org/https://doi.org/10.13031/2013.34828

Babu, A. K., Kumaresan, G., Raj, V. A. A., \& Velraj, R. (2018). Review of leaf drying: Mechanism and influencing parameters, drying methods, nutrient preservation, and mathematical models. Renewable and Sustainable Energy Reviews, 90, 536-556. https://doi.org/10.1016/j.rser.2018.04.002

Bhaktaraj, S., Prajapati, R., Nepal, K., Timalsina, P., \& Mitra, P. (2019). Effect of Sucrose Content ( Obrix ) and Different Flavors on Physical, Mechanical and Sensorial Properties of Ginger Candy. Food Science and Nutrition Technology, 4(2), 1-11. https://doi.org/10.23880/fsnt-16000177

Bratsch, A. (2009). Specialty Crop Profile:Horseradish. Virginia Cooperative Extension, Virginia Polytechnic Institute and State University, USA. Retrieved from https://www.pubs.ext.vt.edu/content/dam/pubs_ext_vt_edu/438/438-104/438-104_pdf.p df

Dhanushkodi, S., Wilson, V. H., \& Sudhakar, K. (2017). Mathematical modeling of drying behavior of cashew in a solar biomass hybrid dryer. Resource-Efficient Technologies, 3(4), 359-364. https://doi.org/10.1016/j.reffit.2016.12.002

Ekechukwu, O. V. (1999). Review of solar-energy drying systems I: An overview of drying principles and theory. Energy Conversion and Management, 40(6), 593-613. https://doi.org/10.1016/S0196-8904(98)00092-2

Kumar, C., Karim, M. A., \& Joardder, M. U. H. (2014). Intermittent drying of food products: A critical review. Journal of Food Engineering, 121(1), 48-57. https://doi.org/10.1016/j.jfoodeng.2013.08.014

Meda, V., Mitra, P., Lee, J. H., \& Chang, K. S. (2016). Optimization of microwave-vacuum drying processing parameters on the physical properties of dried Saskatoon berries. Open Agriculture, 1(1), 7-17. https://doi.org/10.1515/opag-2016-0002

Midilli, A., \& Kucuk, H. (2003). Mathematical modeling of thin layer drying of pistachio by using solar energy. Energy Conversion and Management, 44(7), 1111-1122. https://doi.org/10.1016/S0196-8904(02)00099-7

Mitra, P., Alim, A., \& Meda, V. (2019). Effect of Hot Air Thin Layer Drying Temperature on Physicochemical and Textural Properties of Dried Horseradish. Journal of Food Industry, 3(1), 1-18. https://doi.org/10.5296/jfi.v3i1.15721

Mitra, P., Chang, K. S., \& Yoo, D. S. (2011). Kaempferol Extraction from Cuscuta reflexa using Supercritical Carbon Dioxide and Separation of Kaempferol from the Extracts. In International Journal of Food Engineering 7(4), 1-15. https://doi.org/10.2202/1556-3758.1768

Mitra, P., \& Meda, V. (2009). Optimization of Microwave-Vacuum Drying Parameters of Saskatoon Berries Using Response Surface Methodology. Drying Technology, 27(10), 


\section{Macrothink}

1089-1096. https://doi.org/10.1080/07373930903221101

Mitra, P., Meda, V., \& Green, R. (2013). Effect of drying techniques on the retention of antioxidant activities of Saskatoon berries. International Journal of Food Studies, 2, 224-237. https://doi.org/10.7455/ijfs/2.2.2013.a8

Nagalakshmi, S. A., Mitra, P., \& Meda, V. (2014). Color, Mechanical, and Microstructural Properties of Vacuum Assisted Microwave Dried Saskatoon Berries. International Journal of Food Properties, 17(10), 2142-2156.

Orsat, V., Changrue, V., \& Raghavan, V. G. S. (2006). Microwave drying of fruits and vegetables. Stewart Postharvest Review, 2(6), 1-7. https://doi.org/10.2212/spr.2006.6.4

Sadi, T., \& Meziane, S. (2015). Mathematical modelling, moisture diffusion and specific energy consumption of thin layer microwave drying of olive pomace. International Food Research Journal, 22(2), 494-501.

Sagar, V. R., \& Suresh Kumar, P. (2010). Recent advances in drying and dehydration of fruits and vegetables: a review. Journal of Food Science and Technology, 47(1), 15-26. https://doi.org/10.1007/s13197-010-0010-8

Timalsina, P., Prajapati, R., Bhaktaraj, S., Shrestha, R., Shrestha, S., \& Mitra, P. (2019). Sweet potato chips development and optimization of chips processing variables. Open Agriculture, 4(1), 118-128. https://doi.org/10.1515/opag-2019-0011

Togrul, I. T., \& Pehlivan, D. (2002). Mathematical modelling of solar drying of apricots in thin layers. Journal of Food Engineering, 55(3), 209-216. https://doi.org/10.1016/S0260-8774(02)00065-1

\section{Copyright Disclaimer}

Copyright for this article is retained by the author(s), with first publication rights granted to the journal.

This is an open-access article distributed under the terms and conditions of the Creative Commons Attribution license (http://creativecommons.org/licenses/by/4.0/). 